\title{
PERAN KESEJAHTERAAN KARYAWAN TERHADAP PENINGKATKAN DISIPLIN KERJA KARYAWAN PADA PT. KOBEXINDO TRACTORS TBK CABANG SAMARINDA
}

\author{
Djumar Soewito \\ Dosen Ilmu Administrasi Publik FISIP Universitas Widya Gama Mahakam Samarinda \\ e-mail: djumarsoewito@uwgm.ac.id \\ Kusmayadi \\ Dosen Ilmu Administrasi Publik FISIP Universitas Widya Gama Mahakam Samarinda \\ e-mail: nadar1683@gmail.com \\ Irwansyah \\ Alumni Ilmu Administrasi Publik FISIP Universitas Widya Gama Mahakam Samarinda
}

\begin{abstract}
Abstrak
Perusahaan merupakan suatu organisasi yang mempunyai berbagai macam tujuan. Aktivitas didalam suatu perusahaan selalu ditujukan untuk mencapai tujuan tersebut maka diperlukan pengelolaan faktor-faktor produksi yag terdiri dari sumber daya alam, sumber daya manusia, modal, mesin, dan teknologi. Dalam rangka pembinaan dan pengembangan sumber daya manusia untuk kesejahteraan perlu diperhatikan dengan sungguh-sungguh karena kesejahteraan karyawan merupakan faktor yang menentukan dalam memacu semangat kerja, disiplin, serta produktifitas kerja karyawan. Adapun yang menjadi permasalahan dalam penelitian ini yakni Apakah Kesejahteraan Karyawan Berperan Terhadap Peningkatan Disiplin Kerja Karyawan Pada PT. Kobexindo Tractors Tbk Cabang Samarinda? Tujuan dalam penelitian ini berdasarkan bahasan penelitian dalam latar belakang di atas, sebagai upaya untuk mengetahui sejauh mana peran kesejahteraan karyawan terhadap peningkatkan disiplin kerja karyawan pada PT. Kobexindo Tractors Tbk Cabang Samarinda, mengetahui faktor yang menghambat program kesejahteraan karyawan terhadap peningkatkan disiplin kerja karyawan pada PT. Kobexindo Tractors Tbk Cabang Samarinda, serta menguji kebenaran rumusan hipotesis, berdasarkan jawaban responden. Penelitian ini merupakan penelitian menggunakan metode kuantitatif. Dengan populasi karyawan berjumlah sebanyak 35 orang, dengan gejala kontinum, dimana data yang diperoleh tidak dapat diukur secara langsung, yang diukur dengan skala ordinal.

Hasil penelitian menunjukkan bahwa para responden menyadari bahwa displin dalam bekerja sangat diperlukan. Hal ini terlihat dari jawaban para responden dari berbagai indikator menunjukan hasil yang positif.Berdasarkan hasil dari uji statistik koefisien korelasi rank spearman (rs), dari hasil yang diperoleh yaitu 0,249, ini menunjukan bahwa nilai rank spearman (rs) $0,249<0,283$ berdasarkan tabel harga kritis korelasi koefisien rank spearman sehingga tidak signifikan. Dapat disimpulkan tidak ada hubungan sebab akibat diantara kedua variabel. Dengan demikian menolak hipotesis alternatif (Ha) dan menerima hipotesis null (Ho) berarti bahwa kesejahteraan karyawan tidak berperan terhadap peningkatan disiplin kerja karyawan pada PT. Kobexindo Tractors, Tbk cabang Samarinda. Adapun faktor yang paling mempengaruhi dalam terciptanya disiplin kerja karyawan adalah kemauan orang itu sendiri dalam mentaaati peraturan perusahaan dan pihak perusahaan juga harus tegas dalam menegakkan disiplin pada karyawannya.
\end{abstract}

Kata Kunci: kesejahteraan karyawan, peningkatkan disiplin kerja, PT. Kobexindo tractors tbk cabang samarinda 


\begin{abstract}
The company is an organization that has various purposes. Activity within a company is always aimed to achieve that goal it is necessary management of production factors consisting of natural resources, human resources, capital, machinery, and technology. In the framework of fostering and developing human resources for welfare need to be considered seriously because the welfare of employees is a decisive factor in spur employee morale, discipline, and employee productivity. As for the problems in this research that Is Employee Welfare Participant Against Increasing Employee Discipline At PT. Kobexindo Tractors Tbk Samarinda Branch? The purpose of this study based on the research in the background above, as an effort to determine the extent to which the employee welfare role to improve employee discipline at PT. Kobexindo Tractors Tbk Branch Samarinda, knowing the factors that hamper employee welfare programs to increase employee discipline at PT. Kobexindo Tractors Tbk Branch Samarinda, and test the truth of hypothesis formulation, based on respondents' answers.

The results showed that respondents realized that discipline in work is necessary. This is seen from the answers of the respondents from various indicators showed a positive result. Based on the results of statistical tests of rank spearman correlation coefficient (rs), from the results obtained that is 0.249 , it shows that the value of spearman rank (rs) 0.249 $<0.283$ based on the price table critical correlation coefficient rank spearman so it is not significant. It can be concluded that there is no causal relationship between the two variables. Thus rejecting the alternative hypothesis (Ha) and accept the null hypothesis (Ho) means that the welfare of employees does not contribute to the improvement of employee discipline at PT. Kobexindo Tractors, Tbk Samarinda branch. The factors that most affect in the creation of employee discipline is the willingness of the person himself in obeying the rules of the company and the company must also be firm in enforcing discipline on employees.
\end{abstract}

Keywords: employee welfare, improvement of work discipline, PT. Kobexindo tractors tbk samarinda branch

\title{
1. Pendahuluan
}

Perusahaan merupakan suatu organisasi yang mempunyai berbagai macam tujuan. Aktivitas didalam suatu perusahaan selalu ditujukan untuk mencapai tujuan tersebut maka diperlukan pengelolaan faktor-faktor produksi yag terdiri dari sumber daya alam, sumber daya manusia, modal, mesin, dan teknologi.

Perusahaan harus selalu memperhatikan keterkaitan antara faktor-faktor produksi tersebut. Dengan demikian perusahaan dituntut untuk dapat mengelola perusahaan dengan sebaik-baiknya terutama pada bidang sumber daya manusia. Hal tersebut perlu dilakukan agar karyawan sebagai sumber daya terpenting mampu bekerja lebih baik dan efisien dalam mencapai tujuan perusahaan. Jika suatu organisasi ingin berkembang dengan pesat, organisasi harus mempunyai sumber daya manusia yang mampu menampilkan kinerja yang baik.

Dalam rangka pembinaan dan pengembangan sumber daya manusia untuk kesejahteraan perlu diperhatikan dengan sungguh-sungguh karena kesejahteraan karyawan merupakan faktor yang menentukan dalam memacu semangat kerja, disiplin, serta produktifitas kerja karyawan.

Menurut UU RI No. 11 tahun 2009 tentang kesejahteraan sosial disebutkan bahwa "Kesejahteraan sosial adalah kondisi terpenuhinya kebutuhan material, spiritual dan 
sosial warga negara agar dapat hidup layak dan dapat mengembangkan diri sehingga dapat melaksanakan fungsi sosialnya". Dalam hal ini kesejahteraan yang diberikan perusahaan kepada karyawan sebagai balas jasa baik material maupun non material merupakan faktor yang dapat memacu meningkatkan disiplin kerja dari karyawan. Sementara berdasarkan penjelasan Syafruddin (anggota DPRD. Partai Kebangkitan Bangsa), dalam koran harian

Tribun Kaltim, tanggal 21 Mei 2016, Beliau mengungkapkan bahwa: "Upah Minimum Provinsi tahun 2015 sebesar Rp 2.026.126 sedangkan Upah Minimum Provinsi sejak 1 Januari 2016 sebesar Rp. 2.161.253. Besaran Upah Minimum Provinsi (UMP) yang telah ditetapkan Dewan Pengupahan Provinsi (DPP) dinilai tidak akan mencukupi kebutuhan hidup pekerja selama satu bulan." Hal ini menyebabkan kurangnya disiplin kerja para karyawan pada parusahaan-perusahaan yang mengakibatkan turunnya produktivitas kerja, tingkat absensi, dan semangat kerja karyawan.

Bertitik tolak dari apa yang telah diuraikan diatas, begitu pula halnya yang terjadi pada perusahaan PT. Kobexindo Tractors, Tbk Cabang Samarinda. PT. Kobexindo Tractors, Tbk adalah salah satu perusahan yang bergerak dibidang supplier alat berat (dealer) dengan merek DOOSAN. Perusahaan ini mulai membuka cabang di Samarinda mulai tahun 2010 dengan fokus penjualan disektor pertambangan. Awalnya PT. Kobexindo Tractors, Tbk khusus di Kalimantan Timur hanya membuka cabang dikota Balikpapan saja akan tetapi semakin pesatnya kebutuhan perusahaan-perusahaan yang bergerak disektor pertambangan dalam pengadaan unit alat berat maka dibukalah cabang di kota Samarinda.

PT. Kobexindo Tractors Tbk juga mengutamakan tingkat kesejahteraan karyawan sesuai dengan peraturan perundang-undangan yang ada. Pelaksanaan program kesejahteraan karyawan misalnya memberikan tunjangan hari tua, memberikan cuti, memberikan tunjangan kesehatan, menyediakan fasilitas-fasilitas, serta memperhatikan keamanan kerja untuk menjamin perlindungan kondisi fisik dan mental karyawan yang pada akhirnya dapat mendorong disiplin kerja karyawan.

Berkaitan dengan program kesejahteraan karyawan inilah yang membuat peneliti ingin meneliti lebih dalam apakah benar gaji karyawan mengalami kenaikan tiap tahunnya, insentif untuk sales dan marketing dibayar sesuai ketentuan perusahaan, kenaikan jabatan dan bonus para karyawan benar dilakukan sesuai dengan program kesejahteraan tersebut. Dari hasil observasi awal peneliti pada objek penelitian yaitu di PT. Kobexindo Tractors Tbk cabang Samarinda, penulis menemukan beberapa masalah yang merupakan gejala rendahnya dalam disiplin kerja karyawan, hal ini dapat terlihat dari :

1. Masih ada karyawan yang terlambat masuk kerja

2. Adanya kecenderungan untuk memperlambat dalam proses penyelesaian pekerjaan dan pemborosan jam kerja

3. Masih ada karyawan yang belum mampu menyelesaikan pekerjaan tepat pada waktunya

4. Kurangnya etos kerja dari masing-masing karyawan.

\subsection{Permasalahan}

Adapun yang menjadi permasalahan dalam penelitian ini yakni Apakah Kesejahteraan Karyawan Berperan Terhadap Peningkatan Disiplin Kerja Karyawan Pada PT. Kobexindo Tractors Tbk Cabang Samarinda?

\subsection{Tujuan}


Adapun yang menjadi tujuan dalam penelitian ini berdasarkan bahasan penelitian dalam latar belakang di atas, sebagai upaya untuk mengetahui sejauh mana peran kesejahteraan karyawan terhadap peningkatkan disiplin kerja karyawan pada PT. Kobexindo Tractors Tbk Cabang Samarinda, mengetahui faktor yang menghambat program kesejahteraan karyawan terhadap peningkatkan disiplin kerja karyawan pada PT. Kobexindo Tractors Tbk Cabang Samarinda, serta menguji kebenaran rumusan hipotesis, berdasarkan jawaban responden.

\section{Kerangka Teori}

\subsection{Kesejahteraan Karyawan}

Berkaitan dengan kesejahteraan karyawan jika dikaitkan dengan tujuan Negara Indonesia. Negara didirikan, dipertahankan dan dikembangkan untuk kepentingan seluruh rakyat yaitu untuk menjamin dan memajukan kesejahteraan umum. Hal ini secara nyata dituangkan dalam pembukaan Undang-Undang Dasar Negara Republik Indonesia Tahun 1945 yang berbunyi: "Kemudian daripada itu untuk membentuk suatu pemerintah Negara Indonesia yang melindungi segenap bangsa Indonesia dan seluruh tumpah darah Indonesia dan untuk memajukan kesejahteraan umum, mencerdaskan kehidupan bangsa dan ikut melaksanakan ketertiban dunia berdasarkan kemerdekaan, perdamaian abadi dan keadilan sosial, maka disusunlah kemerdekaan kebangsaan Indonesia itu dalam suatu Undang-Undang dasar Negara Indonesia."

Dalam UU RI No. 13 tahun 2003 memberikan pengertian tentang kesejahteraan pekerja yaitu suatu pemenuhan kebutuhan dan atau keperluan yang bersifat jasmaniah dan rohaniah, baik didalam maupun diluar hubungan kerja, yang secara langsung atau tidak langsung dapat mempertinggi produktifitas kerja dalam lingkungan kerja yang aman dan sehat.

Perwujudan masyarakat yang adil dan makmur secara lebih rinci disebutkan oleh Aristoteles dalam Kirdi Dipoyudo (1998:12), tersedianya : 1. Cukup sandang dan pangan dan perumahan yang layak, sehingga ia dapat hidup dengan aman tidak perlu merasa cemas dalam menghadapi kehidupan dimasa yang akan datang; 2. Fasilitas kesehatan termasuk tenaga medis, obat-obatan, rumah sakit dan pusat kesehatan masyarakat dengan perlengkapan dan tenaga yang memadai dengan biaya yang terjangkau daya beli masyarakat; 3 . Kesempatan pendidikan dalam segala tingkat baik pendidikan umum atau profesional kejuruan; 4. Jaminan hari tua, sehingga orang tidak takut menghadapi masa tuanya pada saat dia tidak bisa berdaya mencari nafkah; 5. Sarana perhubungan secukupnya, sehingga dia dengan mudah, cepat dan murah untuk bergerak dalam menghadapi segala urusannya; 6. Sarana komunikasi seperlunya, sehingga dapat mengadakan hubungan dengan orang lain melalui pos, telepon, telegram dan radio dengan cepat dan mudah; 7. Kesempatan kerja yang sesuai keinginan dan kecakapannya; 8. Kesempatan untuk mengembangkan dan menikmati kebudayaan, menyempurnakan hidup moral keagamaan dan kehidupan intelektualnya; 9. Memungkinkan untuk istirahat dan menikmati hiburan; Menurut Malayu S.P Hasibuan (2007:185), "Kesejahteraan adalah balas jasa lengkap (materi dan non materi) yang diberikan oleh pihak perusahaan berdasarkan kebijaksanaan. Tujuannya untuk mempertahankan dan memperbaiki kondisi fisik dan mental karyawan agar produktifitasnya meningkat". Karyawan merupakan unsur yang sangat penting yang berperan aktif didalam kegiatan organisasi atau perusahaan. Salah satu cara yang dilakukan oleh perusahaan untuk mempertahankan karyawan adalah dengan melaksanakan program kesejahteraan kepada seluruh karyawan.

Program kesejahteraan karyawan merupakan salah satu cara untuk meningkatkan disiplin kerja karyawan. Program kesejahteraan yang diberikan oleh perusahaan, lembaga 
atau organisasi pada karyawannya hendaknya bermanfaat, sehingga dapat mendorong tercapainya tujuan perusahaan yang efektif.

Menurut Saksono (2000:40-41) ada beberapa bentuk pemberian kesejahteraan untuk karyawan antara lain :

1. Upah dan gaji dalam bentuk uang : Struktur upah dalam bentuk uang tersusun dari berbagai komponen upah, yaitu : upah pokok, tunjangan keluarga, tunjangan pendidikan, uang makan, uang transport, tunjangan jabatan.

2. Upah dan gaji dalam bentuk barang.

Menurut Malayu S.P Hasibuan (2001:187), tujuan pemberian kesejahteraan karyawan antara lain sebagai berikut:

1. Untuk meningkatkan kesetiaan dan keterikatan karyawan kepada perusahaannya

2. Memberikan ketenangan dan pemenuhan kebutuhan bagi karyawan beserta keluarganya

3. Memotivasi gairah kerja, disiplin, dan produktifitas kerja karyawannya

4. Menurunkan tingkat absensi dan turnover karyawan

5. Menciptakan lingkungan dan suasana kerja yang baik serta nyaman

6. Membantu lancarnya pelaksanaan pekerjaan untuk mencapai tujuannya

7. Memelihara kesehatan dan meningkatkan kualitas karyawannya

8. Mengefektifkan pengadaan karyawan

9. Membantu pelaksanaan program pemerintah dalam meningkatkan kualitas manusia Indonesia

10. Mengurangi kecelakaan dan kerusakan peralatan kantor

11. Meningkatkan status sosial karyawan beserta keluarganya.

Menurut Ishak Arep (2003:202), berdasarkan bentuk kesejahteraan, secara garis besar dipaparkan bahwa kesejahteraan terdiri dari 2 jenis :

1. Kesejahteraan langsung : Kesejahteraan langsung adalah penghargaan yang berupa gaji, upah yang dibayar secara tetap berdasarkan tenggang waktu yang tetap dan insentif adalah penghargaan yang diberikan untuk memotivasi karyawan agar produktifitas kerjanya tinggi, sifatnya tidak tetap dan sewaktu-waktu.

2. Kesejahteraan tidak langsung : Kesejahteraan tidak langsung adalah pemberian dari keuntungan/manfaat lainnya bagi para karyawan diluar gaji atau upah dan bonus yang dapat berupa barang atau tunjangan.

Menurut T. Hani Handoko (2001:183), "Kesejahteraan tidak langsung adalah balas jasa pelengkap atau tunjangan yang diberikan pada karyawan berdasarkan kemampuan perusahaan". Sedangkan menurut Gouzali Saydam (2002:234), "Bentuk dan jenis kesejahteraan yang dapat diberikan kepada karyawan adalah gaji, upah, tunjangan, dan insentif atau bonus. Selain program kesejahteraan berupa uang, dapat pula diberikan berupa tunjangan". Tunjangan ini dapat berupa tunjangan keluarga, tunjangan pembangunan dan sebagainya yang kesemuanya dapat menambah pernghasilan karyawan". Sedangkan menurut Mutiara S. Panggabean (2004:316), "Kesejahteraan karyawan juga mencakup semua jenis penghargaan berupa uang yang tidak dibayarkan secara langsung kepada karyawan". Sedangkan menurut Hadari Nawawi (2001:316), 
"Program pemberian penghargaan atau ganjaran dengan variasi yang luas, sebagai bagian keuntungan organisasi atau perusahaan".

Menurut Malayu S.P Hasibuan (2007:188) jenis kesejahteraan yang akan diberikan harus selektif dan efektif mendorong terwujudnya tujuan organisasi, karyawan dan keluarganya. Jenis program kesejahteraan dapat disajikan dengan tabel sebagai berikut

Berdasarkan teori diatas, dapat disimpulkan bahwa kesejahteraan karyawan merupakan suatu upaya atau usaha perusahaan untuk meningkatkan semangat kerja, disiplin kerja, produktifitas kerja, dan loyalitas karyawan terhadap perusahaan dengan cara memenuhi kebutuhan karyawan itu sendiri seperti gaji/upah, bonus, tunjangantunjangan, fasilitas, dll, sesuai dengan kemampuan perusahaan sehingga dapat membuat karyawan merasa senang, aman, dan nyaman bekerja di perusahaan.

\subsection{Disiplin Kerja Karyawan}

Secara umum disiplin adalah taat kepada hukum dan peraturan yang berlaku. Disiplin juga berkaitan erat dengan sanksi yang perlu dijatuhkan kepada pihak yang melanggar. Menurut Muchdarsyah Sinungan (2003:135), "Disiplin adalah sikap kejiwaan seseorang/kelompok orang yang senantiasa berkehendak untuk mengikuti/mematuhi segala aturan/keputusan yang ditetapkan". Dalam hal ini seorang karyawan yang melanggar peraturan yang berlaku dalam suatu perusahaan, maka karyawan yang bersangkutan harus sanggup menerima hukuman yang telah disepakati.

Menurut Malayu S.P Hasibuan (2007:193), "Disiplin adalah kesadaran dan kesediaan seseorang menaati semua peraturan perusahaan dan norma-norma sosial yang berlaku".

Disiplin kerja merupakan salah satu fungsi operatif yang terpenting dan tidak dapat diabaikan karena sebagai bagian dari fungsi pemeliharaan karyawan dan bilamana semakin baik disiplin kerja karyawan, makin tinggi prestasi kerja yang dapat dicapainya. Menurut Alex S. Nitisemito (2002:199), "Disiplin adalah suatu sikap, tingkah laku, dan perbuatan yang sesuai dengan peraturan perusahaan baik yang tertulis maupun tidak tertulis". Sedangkan menurut Robert L. Mathis dan John H. Jackson (2002:314) "Disiplin adalah bentuk pelatihan yang menegakkan peraturan-peraturan perusahaan". Dengan disiplin kerja yang baik pada diri karyawan, maka akan semakin tinggi prestasi kerja yang akan dicapainya.

Menurut pendapat T. Hani Handoko (2001:208), "Disiplin adalah kegiatan manajemen untuk menjalankan standar- standar organisasional, disiplin terbagi menjadi 3 (tiga) disiplin kerja, yaitu :

1. Displin Preventif yaitu: kegiatan yang dilaksanakan untuk mendorong para karyawan agar mengikuti berbagai standar dan aturan, sehingga penyelewengan dapat dicegah.

2. Disiplin Korektif yaitu: kegiatan yang diambil untuk menangani pelanggaran terhadap aturan-aturan yang mencoba untuk menghindari pelanggaran-pelanggaran lebih lanjut. Kegiatan korektif sering berupa suatu bentuk hukuman dan disebut tindakan pendisiplin.

3. Disiplin Progresif yaitu: kegiatan memberikan hukuman-hukuman yang lebih berat terhadap pelanggaran-pelanggaran yang berulang. Tujuannya adalah memberikan kesempatan kepada karyawan untuk mengambil tindakan korektif sebelum hukuman-hukuman yang lebih serius dilaksanakan.

Banyak faktor yang dapat mempengaruhi tegak tidaknya suatu disiplin kerja dalam suatu perusahaan. Menurut Gouzali Saydam (2006:202), faktor-faktor tersebut antara lain: 
1. Besar kecilnya pemberian kompensasi

2. Ada tidaknya keteladanan pimpinan dalam perusahaan

3. Ada tidaknya aturan pasti yang dapat dijadikan pegangan

4. Keberanian pimpinan dalam mengambil tindakan

5. Ada tidaknya pengawasan pimpinan

6. Ada tidaknya perhatian kepada pada karyawan

7. Diciptakan kebiasaan-kebiasaan yang mendukung tegaknya disiplin

Setyawan dan Waridin (2006:185), mengemukakan 5 (lima) faktor dalam penilaian disiplin kerja terhadap pemberian layanan pada masyarakat, antara lain :

1. Kualitas kedisiplinan kerja, meliputi datang dan pulang tepat waktu, pemanfaatan waktu untuk pelaksanaan tugas dan kemampuan mengembangkan potensi diri berdasarkan motivasi yang positif,

2. Kuantitas perkerjaan meliputi volume keluaran dan kontribusi,

3. Kompensasi yang diperlukan meliputi saran, arahan atau perbaikan,

4. Lokasi tempat kerja atau tempat tinggal

5. Konservasi meliputi penghormatan terhadap aturan dengan keberanian untuk selalu melakukan pencegahan terjadinya tindakan yang bertentangan dengan aturan.

Sedangkan menurut Veithzal Rivai (2005:444), mengemukakan faktor penilaian disiplin kerja karyawan yaitu :

1. Absensi atau kehadiran

2. Ketaatan pada peraturan kerja

3. Ketaatan pada standart kerja

4. Tingkat kewaspadaan tinggi

5. Bekerja etis

Menurut Alex S. Nitisemito (2002:123), "Beberapa hal yang dapat menunjang keberhasilan dalam pendisiplinan karyawan yaitu:

1. Ancaman : Dalam rangka menegakkan kedisiplinan kadang kala perlu adanya ancaman meskipun ancaman yang diberikan tidak bertujuan untuk menghukum, tetapi lebih bertujuan untuk mendidik supaya bertingkah laku sesuai dengan yang kita harapkan.

2. Kesejahteraan : Untuk menegakkan kedisiplinan maka tidak cukup dengan ancaman saja, tetapi perlu kesejahteraan yang cukup yaitu besarnya upah yang mereka terima, sehingga minimal mereka dapat hidup secara layak.

3. Ketegasan : Jangan sampai kita membiarkan suatu pelanggaran yang kita ketahui tanpa tindakan atau membiarkan pelanggaran tersebut berlarut-larut tanpa tindakan yang tegas.

4. Partisipasi : Dengan jalan memasukkan unsur partisipasi maka para karyawan akan merasa bahwa peraturan tentang ancaman hukuman adalah hasil persetujuan bersama. 
5. Tujuan dan Kemampuan : Agar kedisiplinan dapat dilaksanakan dalam praktek, maka kedisiplinan hendaknya dapat menunjang tujuan perusahaan serta sesuai dengan kemampuan dari karyawan.

6. Keteladanan Pimpinan : Mempunyai pengaruh yang sangat besar dalam menegakkan kedisiplinan sehingga keteladanan pimpinan harus diperhatikan."

Menurut A.S. Moenir (2006:96), ada 2 (dua) jenis disiplin, yaitu :

1. Disiplin waktu : adalah jenis disiplin yang paling mudah dilihat dan dikontrol baik oleh manajemen yang bersangkutan maupun oleh masyarakat. Disiplin terhadap jam kerja misalnya melalui sistem daftar absensi yang baik dapat dipantau secara tepat dan cepat

2. Disiplin kerja : pada dasarnya terdiri dari metode pengerjaan, prosedur kerjanya, waktu dan jumlah unit yang telah ditetapkan dan mutu yang telah dibakukan. Aturan kerja ini dicakup satu istilah disiplin kerja. Betapapun tersedianya peralatan canggih yang serba otomatis, disiplin kerja dari tenaga kerja tetap menjadi andalan utama.

Menurut Agus Dharma (2004:388), perilaku tidak disiplin yang sering dijumpai ditempat kerja adalah sebagai berikut :

1. Melanggar peraturan jam istirahat dan peraturan jam kerja lainnya

2. Melanggar peraturan keamanan dan kesejahteraan

3. Terlambat masuk kerja dan mangkir dari pekerjaan

4. Berkembang rasa tidak puas, saling curiga, dan saling melempar rasa tanggung jawab

5. Bekerja dengan ceroboh dan merusak peralatan.

Dari beberapa pendapat diatas, dapat disimpulkan bahwa disiplin kerja adalah sikap ketaatan dan kesetiaan seseorang/sekelompok orang terhadap peraturan tertulis maupun tidak tertulis yang tercermin dalam bentuk tingkah laku dan perbuatan pada suatu organisasi untuk mencapai suatu tujuan tertentu.

\subsection{Hipotesis}

Pada penelitian ini digunakan 2 (dua) hipotesis yaitu hipotesis alternatif dan hipotesis nol, keduanya itu akan dibuktikan dengan jalan analisis data dan pengujian hipotesis, hipotesis yang dimaksud adalah :

Ha. : Diduga kesejahteraan karyawan berperan dalam upaya peningkatan disiplin kerja karyawan pada PT. Kobexindo Tractors Tbk Cabang Samarinda

Ho. : Diduga kesejahteraan karyawan tidak berperan dalam upaya peningkatan disiplin kerja karyawan pada PT. Kobexindo Tractors Tbk Cabang Samarinda

\subsection{Definisi Operasional}

Definisi operasional yang diperlukan untuk mengukur variable-variabel yang diteliti dengan indikator-indikator sebagai berikut :

a. Independen variabel atau kesejateraan dengan indikator sebagai berikut:

1. Gaji

2. Insentif 
3. Tunjangan

4. Fasilitas

b. Dependen variabel atau disiplin kerja karyawan dengan indikator, meliputi :

1. Absensi atau kehadiran

2. Ketaatan terhadap peraturan

3. Kewaspadaan tinggi dalam bekerja

4. Bekerja sesuai standart operating procedure (SOP)

Berdasarkan indikator-indikator diatas dapat diketahui kesejahteraan mempunyai pengukuran dari gaji, insentif, tunjangan, dan fasilitas. Sedangkan disiplin kerja dapat diukur dari absensi atau kehadiran, ketaatan terhadap peraturan, kewaspadaan tinggi dalam bekerja, dan bekerja sesuai standart operating procedure (SOP). Dengan demikian diharapkan kesejahteraan dapat berperan dalam meningkatkan disiplin kerja melalui program kesejahteraan perusahaan dalam menunjang kebutuhan karyawan.

\section{Metode}

Penelitian ini merupakan penelitian menggunakan metode kuantitatif. Dengan pendekatan verifikatif, yaitu penelitian yang ditujukan untuk mencari peranan dari kedua variabel yang diteliti, yaitu kesejateraan sebagai independen variabel dan disiplin kerja karyawan sebagai dependen variabel.

Adapun populasi karyawan tersebut yang berjumlah sebanyak 35 orang, dengan gejala kontinum, dimana data yang diperoleh tidak dapat diukur secara langsung, yang diukur dengan skala ordinal.

Untuk menganalisis data yang diperoleh, dan menjawab hipotesis yang telah dirumuskan, peneliti menggunakan formulasi Koefisien Korelasi Rank Spearman (rs) yang dikutip oleh Sidney Siegel (1997:251) sebagai berikut :

a. Jika dalam perhitungan terdapat angka sama atau kembar maka digunakan rumus:

$$
\begin{aligned}
r_{S} & =\frac{\sum x^{2}+\sum y^{2}-\sum d_{i^{2}}}{2 \sqrt{\sum x^{2} \cdot \sum y^{2}}} \\
\text { Dimana } \quad \sum \mathrm{x} 2 & =\frac{\mathrm{N} 3-\mathrm{N}}{12}-\sum \mathrm{Tx} \\
\sum \mathrm{y} 2 & =\frac{\mathrm{N} 3-\mathrm{N}}{12}-\sum \mathrm{Ty} \\
\mathrm{T} & =\frac{\mathrm{t} 3-\mathrm{t}}{12}
\end{aligned}
$$

Keterangan :

rs $=$ Koefisien Korelasi Rank Spearman

di2 = Jumlah keseluruhan di2 dimana di adalah harga masing-masing subyek yang didapat dari selisih antara ranking $\mathrm{x}$ dengan ranking

y. 
$\mathrm{N}=$ Populasi penelitian

$\mathrm{x}=$ Independen variabel

$\mathrm{y}=$ Dependen variabel

$\mathrm{T}=$ Faktor Koreksi

$12=$ Bilangan Tetap

$\mathrm{t}=$ Banyak obserpasi yang berangka sama pada suatu ranking tertentu.

b. Jika dalam perhitungan tidak terdapat angka sama atau kembar, digunakan rumus:

$$
\mathrm{r}_{\mathrm{S}}=1-\frac{6 \sum_{\mathrm{i}=1 \mathrm{~d}_{\mathrm{i}}^{2}}^{\mathrm{N}}}{\mathrm{N}^{3}-\mathrm{N}}
$$

Setelah didapat rs empiris, dibandingkan dengan rs teoritis (tabel) pada $\mathrm{N}$ kasus pada tingkat signifikansi $\alpha$ 0,05. Apabila rs empiris lebih besar atau sama dengan rs tabel, terdapat peranan independen variabel dengan dependen variabel. Sebaliknya apabila rs empiris lebih kecil dari rs tabel, tidak berperan independen variabel dengan dependen variabel.

Setelah tes signifikansi dari harga rs empiris yang dihasilkan dengan perhitungan diatas, dapat disimpulkan sebagai berikut :

1. Jika harga peranan empiris lebih kecil $<$ dari nilai tabel pada tingkat siqnifikansi $\alpha$ 0,05 , maka rs empiris tersebut tidak signifikan, dengan demikian menolak hipotesis alternatif (Ha) dan menerima hipotesis Null (Ho).

2. Jika harga peranan empiris lebih besar $>$ dari nilai tabel pada tingkat signifikansi $\alpha$ 0,05 , harga peranan empiris tersebut signifikan, sehingga menerima hipotesis alternatif (Ha) dan menolak hipotesis Null (Ho).

\section{Hasil}

4.1. Analisis data dan pengujian hipotesis

Adapun analisis data dan pengujian hipotesis yang dilakukan adalah dengan menggunakan koefisien korelasi rank spearman dengan simbol rs, adapun langkahlangkah didalam melakukan analisis data ini adalah sebagai berikut :

1. Menentukan ranking $\mathrm{x}$ dan y dari 1 hingga 35 responden

2. Menentukan harga di dengan cara rangking $\mathrm{x}$ dikurang dengan rangking $\mathrm{y}$ atau di $=$ $\mathrm{x}-\mathrm{y}$

3. Menentukan harga di dengan cara mengkuadratkan masing-masing di

4. Menjumlahkah harga di guna mendapat di demikian pula dengan rangking variabel $x, y$ dan di 
5. Mencari nilai dari $\sum \mathrm{x} 2$ dan $\sum \mathrm{y} 2$ berdasarkan populasi dan nilai ranking yang sama dari variabel $\mathrm{x}$ dan rangking yang sama dari vaariabe $\mathrm{y}$

6. Mencari korelasi antara variabel $\mathrm{x}$ dan variabel y menggunakan dengan rumus koefisien korelasi rank spearman

Berikut ini akan peneliti sajikan data tentang nilai dan rangking dari masingmasing variabel seperti tabel berikut :

Berdasarkan tabel tersebut diatas dapat diketahui bahwa dari 35 orang responden yang memberikan jawaban terdapat 8 himpunan yang memiliki angka yang sama untuk variabel X (kesejahteraan karyawan) dan 11 himpunan yang memiliki angka yang sama untuk variabel $\mathrm{Y}$ (disiplin kerja). Untuk variabel $\mathrm{X}$ (kesejahteraan karyawan) yaitu sebagai berikut :

2 subyek yang memiliki angka sama pada skor 32 diberi rangking 2,5

2 subyek yang memiliki angka sama pada skor 31 diberi rangking 4,5

$\checkmark 3$ subyek yang memiliki angka sama pada skor 30 diberi rangking 7

$\checkmark 4$ subyek yang memiliki angka sama pada skor 26 diberi rangking 12,5

5 subyek yang memiliki angka sama pada skor 25 diberi rangking 17

$\checkmark 3$ subyek yang memiliki angka sama pada skor 22 diberi rangking 21

4 subyek yang memiliki angka sama pada skor 21 diberi rangking 24,5

4 subyek yang memiliki angka sama pada skor 19 diberi rangking 29,5

Kemudian untuk variabel Y (disiplin kerja) terdapat 11 himpunan yang memiliki angka yang sama yaitu sebagai berikut:

$\checkmark 2$ subyek yang memiliki angka sama pada skor 31 diberi rangking 3,5

$\neg 3$ subyek yang memiliki angka sama pada skor 30 diberi rangking 6

$\neg 3$ subyek yang memiliki angka sama pada skor 28 diberi rangking 10

$\checkmark 2$ subyek yang memiliki angka sama pada skor 27 diberi rangking 12,5

$\square 2$ subyek yang memiliki angka sama pada skor 25 diberi rangking 15,5

$\checkmark 3$ subyek yang memiliki angka sama pada skor 24 diberi rangking 18

$\square 2$ subyek yang memiliki angka sama pada skor 23 diberi rangking 20,5

- 4 subyek yang memiliki angka sama pada skor 22 diberi rangking 23,5

$\checkmark 4$ subyek yang memiliki angka sama pada skor 21 diberi rangking 27,5

$\checkmark 3$ subyek yang memiliki angka sama pada skor 20 diberi rangking 31

$\checkmark 2$ subyek yang memiliki angka sama pada skor 18 diberi rangking 34,5

Dari uraian data diatas, maka dapat digunakan rumus rank spearman sebagai berikut :

$$
r_{S}=\frac{\sum x^{2}+\sum y^{2}-\sum d_{i^{2}}}{2 \sqrt{\sum x^{2} \cdot \sum y^{2}}}
$$


Namun sebelum mencari koefisien korelasi spearman rs terlebih dahulu dicari $\sum \mathrm{x}$ dan $\sum$ y untuk masing-masing variabel serta harga-harga kritis observasi yang berangka sama $(\mathrm{T})$, dengan rumus sebagai berikut :

$$
\begin{aligned}
& \sum \mathrm{x}^{2}=-\sum \mathrm{Tx} \mathrm{N}^{3}-\mathrm{N} 12 \\
& \sum \mathrm{y}^{2}=-\sum \mathrm{Ty}
\end{aligned}
$$

Sedangkan faktor korelasi $(\mathrm{T})$ dapat dihitung dengan rumus sebagai berikut :

$$
\mathrm{T}=\frac{\mathrm{t}^{3}-\mathrm{t}}{12}
$$

Maka dapat diketahui dengan perhitungan sebagai berikut :

$$
\begin{aligned}
& \sum \mathrm{x}^{2}=\frac{\mathrm{N}^{3}-\mathrm{N}}{12}-\sum \mathrm{Tx} \\
& \sum \mathrm{x}^{2}=\frac{35^{3}-35}{12}-\frac{2^{3}-2}{12}+\frac{2^{3}-2}{12}+\frac{3^{3}-3}{12}+\frac{4^{3}-4}{12}+\frac{5^{3}-5}{12}+\frac{3^{3}-3}{12}+\frac{4^{3}-4}{12}+\frac{4^{3}-4}{12} \\
& =3570-0,5+0,5+2+5+10+2+5+5 \\
& =3570-30 \\
& \sum x^{2}=3540 \\
& \sum \mathrm{y}^{2}=\frac{\mathrm{N}^{3}-\mathrm{N}}{12}-\sum \mathrm{Ty} \\
& \mathrm{Ty}=\frac{\mathrm{t}^{3}-\mathrm{t}}{12} \\
& \sum y^{2}=\frac{35^{3}-35}{12}-\frac{2^{3}-2}{12}+\frac{3^{3}-3}{12}+\frac{3^{3}-3}{12}+\frac{2^{3}-2}{12}+\frac{2^{3}-2}{12}+\frac{3^{3}-3}{12}+ \\
& \frac{2^{3}-2}{12}+\frac{4^{3}-4}{12}+\frac{4^{3}-4}{12}+\frac{3^{3}-3}{12}+\frac{2^{3}-2}{12} \\
& =3570-0,5+2+2+0,5+0,5+2+ \\
& 0,5+5+5+2+0,5 \\
& =3570-20,5 \\
& \sum y^{2}=3549,5
\end{aligned}
$$


Dari perhitungan diatas dapat diketahui bahwa untuk $\sum \mathrm{x} 2=3540$ dan

untuk $\sum$ y2 $=3549,5$ dan $\sum d_{i}{ }^{2}=5319$. Dengan demikian perhitungan korelasi

rank spearman dapat diketahui sebagai berikut :

$$
\begin{aligned}
r_{s} & =\frac{\sum x^{2}+\sum y^{2}-\sum d_{i}^{2}}{2 \sqrt{\sum x^{2} \cdot \sum y^{2}}} \\
r_{s} & =\frac{3540+3549 \cdot 5-5319}{2 \cdot \sqrt{3540 \cdot 3549,5}} \\
& =\frac{1770,5}{2 \cdot \sqrt{12565230}} \\
& =\frac{1770,5}{2 \cdot 3544,7} \\
& =\frac{1770,5}{7089,4} \\
& =0,249
\end{aligned}
$$

\section{Simpulan}

1) Memperhatikan dari berbagai hasil jawaban responden untuk independen variabel yaitu kesejahteraan karyawan pada PT. Kobexindo Tractors, Tbk cabang Samarinda, menunjukan bahwa walaupun pada indikator gaji responden lebih dominan untuk jawaban yang tidak setuju akan tetapi pada indikator lain respoden beranggapan bahwa kesejahteraan karyawan yang diberikan cukup baik dan menunjukan hasil yang positif.

2) Berdasarkan hasil jawaban responden untuk dependen variabel yaitu disiplin kerja karyawan yang terjadi pada PT. Kobexindo Tractors, Tbk cabang Samarinda, menunjukan bahwa para responden menyadari bahwa displin dalam bekerja sangat diperlukan. Hal ini terlihat dari jawaban para responden dari berbagai indikator menunjukan hasil yang positif.

3) Dari keseluruhan populasi yang berjumlah 35 orang dijadikan responden serta hasil jawaban telah melalui perhitungan analisis uji statistik koefisien korelasi rank spearman (rs), diperoleh hasil $\mathrm{rs}=0,249$ 
4) Berdasarkan hasil dari uji statistik koefisien korelasi rank spearman (rs), dari hasil yang diperoleh yaitu 0,249 , ini menunjukan bahwa nilai rank spearman (rs) $0,249<$ 0,283 berdasarkan tabel harga kritis korelasi koefisien rank spearman sehingga tidak signifikan. Dapat disimpulkan tidak ada hubungan sebab akibat diantara kedua variabel. Dengan demikian menolak hipotesis alternatif (Ha) dan menerima hipotesis null (Ho) berarti bahwa kesejahteraan karyawan tidak berperan terhadap peningkatan disiplin kerja karyawan pada PT. Kobexindo Tractors, Tbk cabang Samarinda.

5) Berdasarkan hasil dari jawaban responden, faktor yang paling mempengaruhi dalam terciptanya disiplin kerja karyawan adalah kemauan orang itu sendiri dalam mentaaati peraturan perusahaan dan pihak perusahaan juga harus tegas dalam menegakkan disiplin pada karyawannya.

\section{Daftar Pustaka}

AGUS DHARMA. 2004. Manajemen Suvervisi Cetakan Keenam. Jakarta : PT. Raja Grafindo Persada. ALEX S NITISEMITO. 2002. Manajemen Personalia Edisi Revisi. Jakarta : Ghalia Indonesia.

ANONIM. 2003. Undang-Undang Nomor 13 Tahun 2003 Tentang Kesejahteraan Pekerja 2009. Undang-Undang Nomor 11 Tahun 2009 Tentang Kesejahteraan Sosial

ARISTOTELES DALAM KIRDI DIPOYUDO. 1998. Keadilan Sosial. Jakarta : CV. Rajawali.

A.S. MOENIR. 2006. Manajemen Pelayanan Umum di Indonesia. Jakarta : Bumi Aksara.

AUGUSTY FERDINAND. 2006. Metode Penelitian Manajemen. Semarang : Badan Penerbit Universitas Diponegoro.

BARRY CUSHWAY. 2002. Human Resoure Management. Jakarta : PT. Elex Media Kumputindo.

BUDI SETYAWAN DAN WARIDIN. 2006. Pengaruh Disiplin Kerja Karyawan dan Budaya Organisasi Terhadap Kinerja di Divisi Radiologi RSUP dr. Kariadi. Semarang : JRBI. Vol 2. No. 2.

GOUZALI SAYDAM. 2002. Manajemen Sumber Daya Manusia. Jakarta : Gunung Agung.

HADARI NAWAWI. 2001. Manajemen Sumber Daya Manusia. Jakarta : Bumi Aksara.

HANI T. HANDOKO. 2001. Manajemen Personalia dan Sumber Daya Manusia. Yogyakarta : BPFE.

HEIDJRACHMAN RANUPANDOJO DAN SUAD HUSNAN. 2002. Manajemen Personalia. Yogyakarta : BPFE.

HUSAINI USMAN DAN PURNOMO SETIADY AKBAR. 2004. Metodologi Penelitian Sosial. Jakarta : Bumi Aksara.

HUSEIN UMAR. 2004. Metode Riset Ilmu Administrasi. Jakarta : Gramedia Pustaka Utama.

IRAWAN SOEHARTONO. 1995. Metode Penelitian Sosial. Bandung : PT. Remaja Rosdakarya.

ISHAK AREP DAN HENDRI TANJUNG. 2003. Manajemen Sumber Daya Manusia. Jakarta : Penerbit Universitas Trisakti. 
JONATHAN SARWONO. 2006. Metode Penelitian Kuantitatif dan Kualitatif. Yogyakarta : Graha Ilmu.

KARTINI KARTONO. 1996. Pengantar Metodologi Riset Sosial. Bandung : Mandar Maju.

KOENTJARANINGRAT. 1997. Metode-Metode Penelitian Masyarakat. Jakarta : PT. Gramedia Pustaka Utama.

MALAYU S.P HASIBUAN. 1999. Manajemen Dasar, Pengertian dan Masalah. Jakarta : Bumi Aksara.

MALAYU S.P HASIBUAN. 2007. Manajemen Sumber Daya Manusia. Jakarta : Bumi Aksara.

. 2008. Manajemen Sumber Daya Manusia. Jakarta : Bumi Aksara. CV. Andi Offset

MASRI SINGARIMBUN DAN SOFIAN EFFENDI. 1995. Metode Penelitian Survei. Jakarta : PT. Pustaka LP3ES Indonesia.

Pustaka LP3ES Indonesia.

2006. Metode Penelitian Survei. Jakarta : PT.

MUCHDARSYAH SINUNGAN. 2003. Manajemen Sumber Daya Manusia. Jakarta : Bumi Aksara.

MUDRAJAD KUNCORO. 2003. Metode Riset Untuk Bisnis dan Ekonomi. Jakarta : Erlangga.

MUTIARA S. PANGGABEAN. 2004. Manajemen Sumber Daya Manusia. Bogor : Ghalia Indonesia.

RICKY FERLINDO. 2007. "Faktor-faktor yang mempengaruhi semangat kerja karyawan pada PT. Intan Bersaudara Rokan Hulu". Jurnal Kewirausahaan dan Manajemen. ROBERT L. MANTIS DAN JOHN H. JACKSON. 2002. Manajemen Sumber Daya Manusia. Jakarta : Salemba Empat.

SAKSONO. 2000. Manajemen Sumber Daya Manusia. Jakarta : PT. Salemba Empat.

SASTROHADIWIRYO SISWANTO. 2006. Manajemen Tenaga Kerja Indonesia Pendekatan Administratif dan Operasional. Jakarta : Bumi Aksara.

SCOT SNELL DAN JOHN BOHLANDER. 2010. Principles Of Human Resource Management. South Western : Cengange Learning.

SIDNEY SIEGEL. 1997. Statistik Nonparametrik untuk Ilmu-Ilmu Sosial. Jakarta : PT. Gramedia Pustaka Utama.

SUGIYONO. 2003. Metode Penelitian Bisnis. Bandung : CV. Alfabeta.

SUGIYONO. 2010. Metode Penelitian Kuantitatif Kualitatif dan R\&D. Bandung : CV. Alfabeta.

SUHARSIMI ARIKUNTO. 2010. Prosedur penelitian : Suatu Pendekatan Praktik. Edisi Revisi. Jakarta : Rineka Cipta.

SUKMADINATA. 2006. Metode Penelitian Pendidikan. Bandung : Rosdakarya.

VEITHZAL RIVAI. 2004. Manajemen Sumber Daya Manusia Untuk Perusahaan. Jakarta : PT. Raja Grafindo Persada. 
. 2005. Manajemen Sumber Daya Manusia Untuk Perusahaan. Jakarta : PT. Raja Grafindo Persada.

WIRAWAN. 2009. Evaluasi Sumber Daya Manusia. Jakarta : Salemba Empat.

eJournal Ilmu Pemerintahan, 2014, 2(3) : 3303-3045 ISSN 0000-0000, ejournal.ip.fisipunmul.ac.id

eJournal Ilmu Administrasi Negara, 2015, 3(4) : 1912-1926 ISSN 0000-0000, ejournal.an.fisip-unmul.org

Rafan Dwinanto. 2016. “UMP Kaltim Tidak Manusiawi”. Dalam Harian Tribun Kaltim. 21 Mei 2016. Samarinda

Definisi

Teori https://id.m.wikipedia.org./wiki/Teori?_e_pi_7\%2CPAGE_ID10\%2C35770 94945 (diakses pada tanggal 11 juli 2016)

Disiplin Kerja Karyawan http://jurnal-sdm.blogspot.com/2009/05/disiplin-kerjakaryawan.html (diakses pada tanggal 11 juli 2016) 